University of Rhode Island

DigitalCommons@URI

The Rhode Island Current Conditions Index

Economics

8-1-2020

\title{
Rhode Island Current Conditions Index - August 2020
}

Leonard Lardaro

University of Rhode Island, lardaro@uri.edu

Follow this and additional works at: https://digitalcommons.uri.edu/ricci

Part of the Econometrics Commons

Terms of Use

All rights reserved under copyright.

\section{Recommended Citation}

Lardaro, Leonard, "Rhode Island Current Conditions Index -- August 2020" (2020). The Rhode Island Current Conditions Index. Paper 211.

https://digitalcommons.uri.edu/ricci/211

This Newsletter is brought to you for free and open access by the Economics at DigitalCommons@URI. It has been accepted for inclusion in The Rhode Island Current Conditions Index by an authorized administrator of DigitalCommons@URI.For more information, please contact digitalcommons-group@uri.edu. 


\title{
CURRENT CONDITIONS
}

\section{LEONARD LARDARO, URI}

\author{
Available Online: http: / www.Ilardaro.com/current.htm \\ Twitter: @ladardo
}

VOL XXVIT

NUMBER 9

AUG 2020

While much of Rhode Island's economy has returned to more "normal" levels (whatever that means anymore!), overall, things remain subdued, to say the least. It is clear that parts of our state's economy are moving in the right direction and continue to do so. But unfortunately, the signs of hope these generate continue to be blunted to an uncomfortably large extent by a host of ongoing negatives.

On a yearly basis, things here continue to look bleak. The Current Conditions Index for August remained in severe contraction territory at 25, as only three of its twelve indicators improved. We have now been stuck at that level for the most recent three months. While some indicators have not fallen terribly far from their pre-pandemic levels, that is not the case for many others. Several key indicators remain far below where they were only six or seven months ago. Gauging this is made all the more complicated by an exceptionally large amount of "noise" in the labor market's survey-based data. Furthermore, changes instituted by the federal government in April have resulted in the data since then being more volatile than would likely have been the case had they continued their earlier procedures.

I recently heard someone from the DLT attribute the recently unfavorable indicator values, most notably Rhode Island's Unemployment Rate, to the small sample used to calculate it. Interestingly, that same person never complained about the exact

\begin{tabular}{|c|c|}
\hline \multicolumn{2}{|c|}{ CCI Indicators - \% Change } \\
\hline Government Employment & -1.2 \\
\hline US Consumer Sentiment & -17.4 \\
\hline Single-Unit Permits & $32.7 \mathrm{Y}$ \\
\hline Retail Sales & $3.1 Y$ \\
\hline Employment Services Jobs & -31.2 \\
\hline Priv. Serv-Prod Employment & -8.8 \\
\hline Total Manufacturing Hours & -3.9 \\
\hline Manufacturing Wage & $\mathbf{3 . 8} \mathbf{Y}$ \\
\hline Labor Force & -2.6 \\
\hline Benefit Exhaustions & $\mathbf{8 8 0 . 0}$ \\
\hline New Claims & 545.0 \\
\hline Unemployment Rate (change) & 9.3 \\
\hline & \\
\hline
\end{tabular}

same sample size when the Unemployment Rate was artificially reduced to around 3.4 percent based on a decade-long Labor Force decline. Let me be clear: It is not sample size that is causing these recent problems. Some combination of extreme noise in the data along with seasonal adjustment difficulties and the lack of data smoothing by the federal government is the cause of the "odd" values we are observing. We are now in the midst of a period where tracking the labor market is essentially "follow the bouncing indicator," at least for survey-based data only.

In terms of yearly comparisons, there is little to cheer about with August's data. What is most concerning to me is that the non-

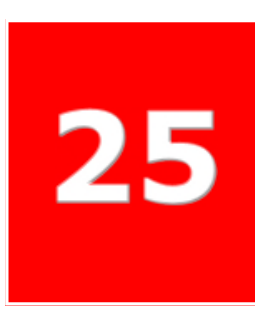

\begin{tabular}{|c|c|c|c|c|}
\hline & Jan & Feb & Mar & Apr \\
\hline 2019 & $58 \downarrow$ & $50 \uparrow$ & 58 & $50 \downarrow$ \\
\hline 2020 & 75 & 75 & 33 & \\
\hline
\end{tabular}

Copyright @ 2018, 2019 Leonard Lardaro, Ph.D. All rights reserved.

survey-based data are showing a disturbing deterioration. Benefit Exhaustions, the best measure of longer-term unemployment, has shot higher from a year-over-year change in June of 153.3 percent to 880 percent in August! New Claims for Unemployment Insurance, a leading economic indicator and the best measure of layoffs, has surged from a 337 percent rise in June to 545 percent in August. At least Retail Sales continues to be an improving indicator, but its rate of improvement has deteriorated noticeably since June.

As has been true of late, the CCI based on monthly changes once again performed better than the yearly-based CCI. And it

\begin{tabular}{|l|r|r|}
\hline CCI Indicators - Monthly $\%$ Change \\
\hline Government Employment & 1.9 & Y \\
\hline US Consumer Sentiment & 3.8 & Y \\
\hline Single-Unit Permits & 34.6 & Y \\
\hline Retail Sales & -2.7 & \\
\hline Employment Services Jobs & 4.5 & Y \\
\hline Priv. Serv-Prod Employment & 1.6 & Y \\
\hline Total Manufacturing Hours & 3.7 & Y \\
\hline Manufacturing Wage & 1.5 & Y \\
\hline Labor Force & -2.8 \\
\hline Benefit Exhaustions & 160.9 \\
\hline New Claims & 15.0 \\
\hline Unemployment Rate (change) & 1.5 \\
\hline \multicolumn{2}{|c|}{ Y = Improved Value } \\
\hline
\end{tabular}

provided us with some good news for a change: The monthly CCI (see above) was 58 in August, reaching an expansion value, as seven of the twelve indicators improved relative to July. Monthover-month changes, if sustained, eventually translate into yearly mprovement. Eleven more to go! We will soon begin to see how long these improvements are able to continue in light of the sizeable number of challenges we will be facing.

\begin{tabular}{|c|c|c|c|c|c|c|c|}
\hline \multicolumn{3}{|c|}{ LABOR FORCE: } & \multicolumn{2}{|c|}{ AUG 2020} & \multicolumn{3}{|c|}{ Peak (1/2007) } \\
\hline \multicolumn{3}{|c|}{ Participation $\mathbf{F}$} & \multicolumn{2}{|c|}{$62.4 \%$} & \multicolumn{3}{|c|}{$68.6 \%$} \\
\hline \multicolumn{3}{|c|}{ Employment Rate } & \multicolumn{2}{|c|}{$54.4 \%$} & \multicolumn{3}{|c|}{$65.4 \%$} \\
\hline \multicolumn{5}{|c|}{$\mathrm{CCl}$ Over the Past 13 Months } & \multirow{2}{*}{\multicolumn{3}{|c|}{$\begin{array}{c}\text { DLT AUG } 2020 \\
\text { Employment } \\
(S A, Y / Y)\end{array}$}} \\
\hline $\begin{array}{l}90 \\
80\end{array}$ & & & & & & & \\
\hline $\begin{array}{l}60 \\
50\end{array}$ & & & & & \multirow{3}{*}{\multicolumn{3}{|c|}{$\begin{array}{cr}\text { Gain } & 1,900 \\
\text { Loss } & 39,100 \\
\text { Net Chg } & (37,200)\end{array}$}} \\
\hline $\begin{array}{l}30 \\
20\end{array}$ & & & & & & & \\
\hline & & $\mathrm{MO}$ & $020 \mathrm{M04} 202$ & & & & \\
\hline May & Jun & $\mathbf{J u l}$ & Aug & Sep & Oct & Nov & Dec \\
\hline $50 \downarrow$ & $58 \downarrow$ & $75 \downarrow$ & 67 & $50 \downarrow$ & $75 \downarrow$ & $58 \downarrow$ & $83 \downarrow$ \\
\hline & & 25 & 225 & & & & \\
\hline
\end{tabular}

